\title{
Entrevista del IMLK en Canal 15
}
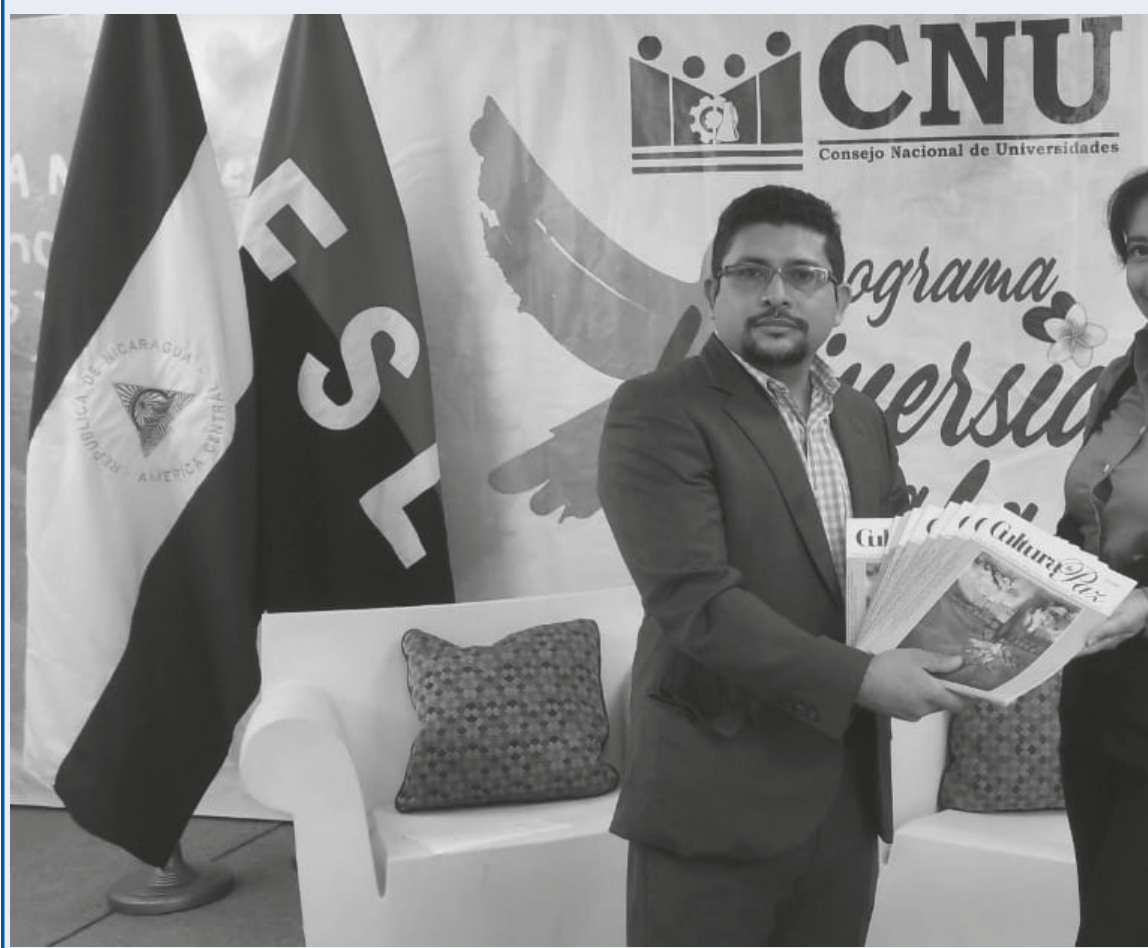

sgrama,
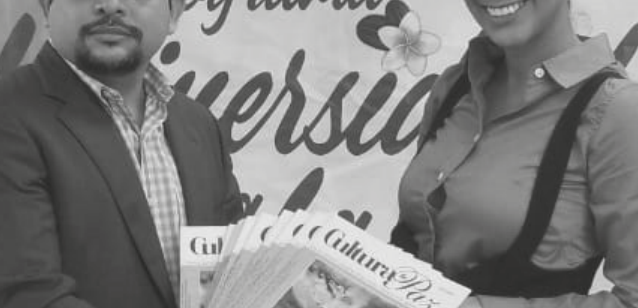

El MSc. Carlos Alberto García Cabrera, Coordinador Académico de Cultura Paz del Instituto Martin Luther King de la Universidad Politécnica de Nicaragua (UPOLI), brindando una entrevista el sábado 22 de agosto 2020, en la que presenta el Paradigma de la Cultura de Paz, en el marco del Programa Universidad para la Paz promovido por el Consejo Nacional de Universidades (CNU), conducido por la periodista María José Aburto Galeano en el Canal 15 de la televisión nacional.

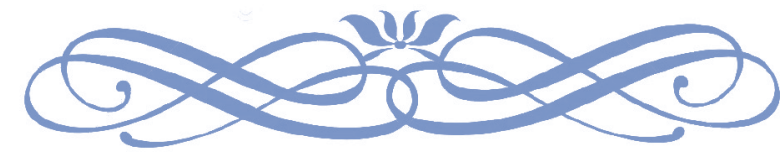

